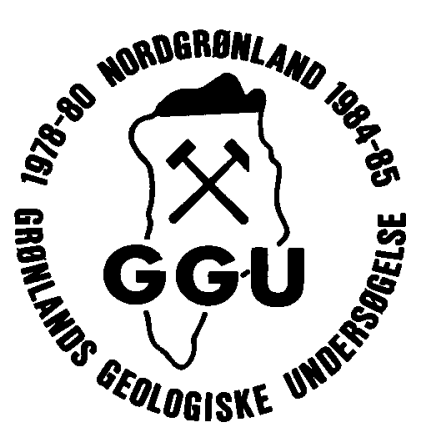

\title{
Precambrian crystalline basement at the head of Victoria Fjord, North Greenland
}

\author{
Niels Henriksen and Hans F. Jepsen
}

\begin{abstract}
Precambrian granites and gneisses outcrop below late Proterozoic and Lower Cambrian sediments in a small area at the margin of the Inland Ice.

The exposed crystalline rocks comprise orthogneisses with scattered amphibolite bands, and occasional horizons of metasediments. The rocks are folded, somewhat migmatised and metamorphosed under amphibolite facies conditions.

Samples for $\mathrm{Rb}-\mathrm{Sr}$ whole rock and $\mathrm{Zr}$ isotopic age determinations have been collected.
\end{abstract}

N. H. \& H. F. J. Grønlands Geologiske Undersøgelse, Øster Voldgade 10, DK-1350 Copenhagen K, Denmark.

Crystalline rocks outcrop at the head of Victoria Fjord over an area of $30 \mathrm{~km}$ by $45 \mathrm{~km}$ at the margin of the Inland Ice on both sides of C. H. Ostenfeld Gletscher (Dawes, 1976). The rocks are found on six nunataks and in two separate areas in south-eastern Wulff Land (fig. 1). These crystalline rocks represent the northernmost exposed part of the Greenland shield. The nearest comparable basement rocks in Greenland are in Inglefield Land $500 \mathrm{~km}$ to the west (Frisch \& Dawes, 1982), and in Kronprins Christian Land $500 \mathrm{~km}$ to the east (Jepsen \& Kalsbeek, 1981). Flat-lying sediments of the late Proterozoic(?) Morænesø Formation and the Lower Cambrian Portfjeld Formation (Jepsen, 1971; O'Connor, 1979) unconformably overlie the crystalline rocks (fig. 2) and indicate a Precambrian age for the basement. The crystalline basement forms a structural high - the Victoria Fjord arch of Dawes \& Soper (1973) - in relation to the overlying sedimentary sequences to the east and west.

The exposed rocks are dominated by homogeneous to weakly banded, foliated biotite gneiss, with scattered conformable black amphibolite sheets. The gneisses grade locally into homogeneous, almost granitic, types and are considered to be orthogneisses. Occasional horizons of prominent amphibolite bands and thin scattered bands of marble, mica schist and siliceous gneisses are interpreted as remnants of supracrustal rock units. All units are somewhat migmatised, and the foliation is generally flat-lying or with gentle dips.

The topographical relief is moderate with undulating small plateaus forming the main part of the area. These plateaus are generally covered with boulders of crystalline rocks and the amount of in situ exposure is limited. Adjacent to the glaciers there are steep cliffs with nearly full exposure, but many of these are difficult of access.

The area was investigated during two helicopter reconnaissance flights and from one camp 


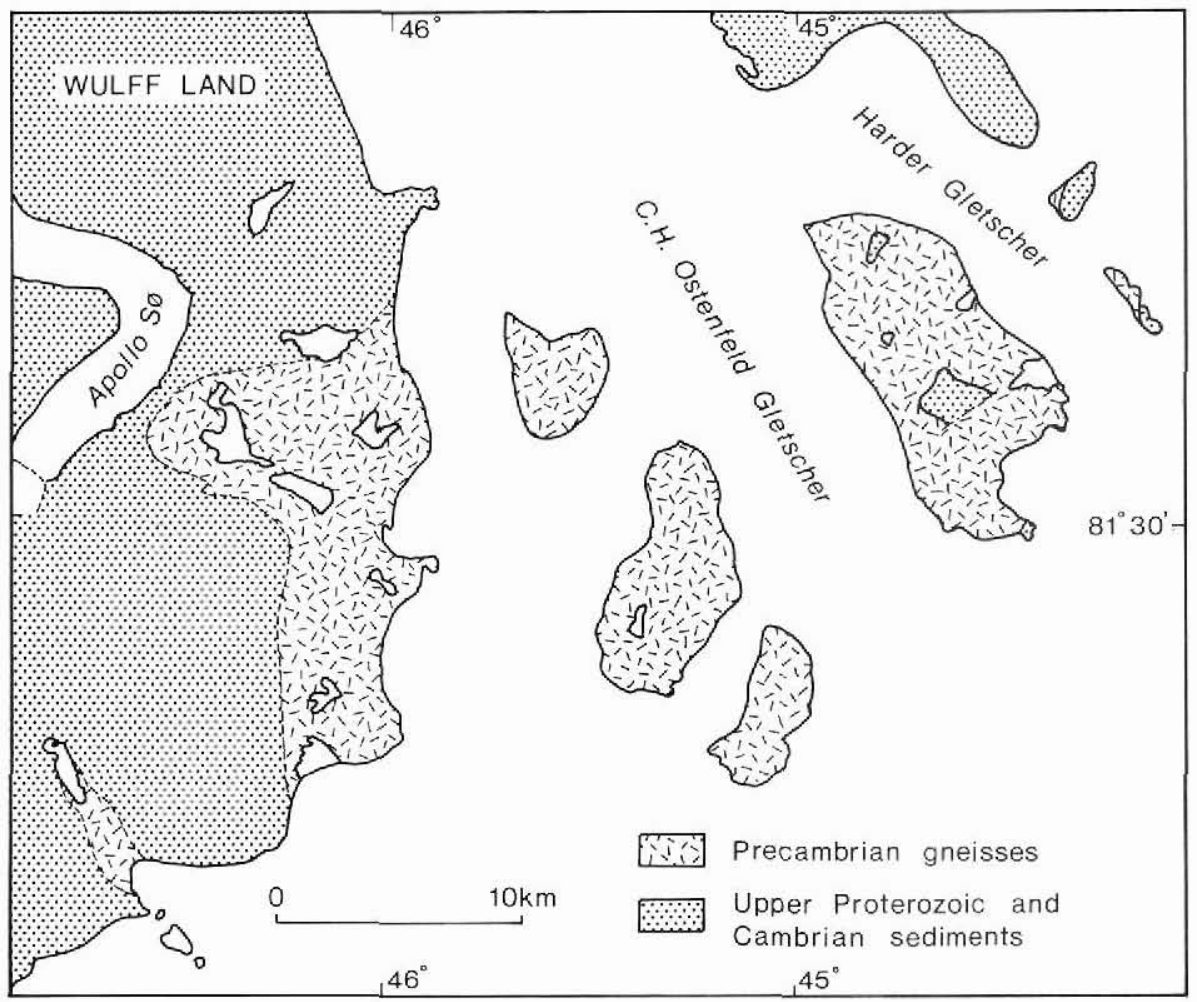

Fig. 1. Sketch map showing distribution of the Precambrian crystalline basement at the head of Victoria Fjord.

on the easternmost nunatak; the main purpose of the latter was to collect material for isotopic age determinations.

\section{Orthogneisses}

The gneisses form more than $90 \%$ of all the exposed crystalline basement rocks. They have a grey, locally pinkish, weathering colour and are homogeneous to weakly banded. Towards the south, both on the nunataks and in Wulff Land, the gneisses grade into more homogeneous, nebulitic types where the banding is very faint or non-existent. These types are clearly of plutonic origin and their gradational transition into more banded types suggests an initial plutonic origin for the main part of the gneisses.

Lithologically the gneisses are medium-grained, foliated, granitic to granodioritic biotite gneisses, often quartz-rich and in places tonalitic. The mafic index is generally between 5 and 10, but some dark bands may have a higher proportion of mafic minerals. Muscovite occurs in some types and garnet, opaque minerals, apatite, sphene and zircon have been noted as accessories. Chlorite, epidote and saussurite occur as secondary minerals in only small amounts, except in secondarily altered joints and crush zones. 


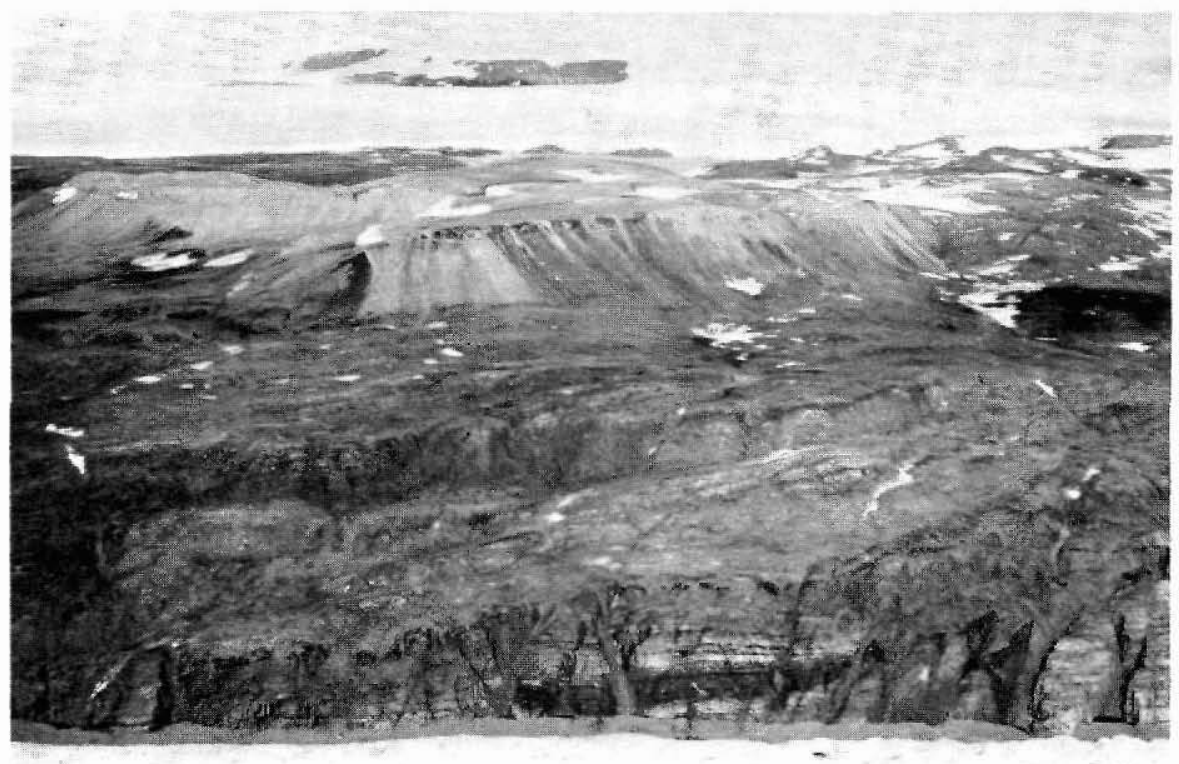

Fig. 2. Proterozoic - Cambrian sedimentary cover (light colour) resting unconformably on the Precambrian basement of orthogneiss with amphibolite sheets. Nunatak east of $\mathrm{C}$. H. Ostenfeld Gletscher looking east.

The gneisses are everywhere somewhat migmatised, and the intensity of migmatisation is clearly higher in the northern parts of the area, where there may be $10-15 \%$ neosome material in the more banded types.

Collections for two $\mathrm{Rb}-\mathrm{Sr}$ whole rock and three $\mathrm{Zr}$ isotopic age determinations have been made from homogeneous types of orthogneisses.

\section{Amphibolite sheets}

The orthogneisses everywhere include conformable black amphibolite sheets, mainly between 1 and $10 \mathrm{~m}$ wide, but occasionally up to 20 or $30 \mathrm{~m}$ wide. The amphibolite sheets occur with an irregular density and form a few percent of the total exposure. They can in many places be traced for several hundred metres and frequently thin out laterally sometimes continuing at a slightly different level in the gneisses and forming en echelon structures. The amphibolites have sharp contacts, and have fine-grained border zones and medium-grained central parts. They are foliated and may contain feldspar porphyroblasts. The amphibolites comprise $50-70 \%$ hornblende, plagioclase (oligoclase-andesine), quartz, garnet, biotite, and in a few examples scapolite. Accessories include opaque minerals and sphene. Sericite, saussurite, epidote and chlorite occur as secondary minerals.

The amphibolite sheets are conformable with the adjacent structures in their host rock and reflect both the local and the regional structures. They are often boudinaged and are cut by scattered pegmatites, especially in the pressure shadows between the boudinaged lenses. 
The amphibolite sheets are most probably former basic intrusions in the orthogneisses, but no direct proof has been found for this interpretation.

\section{Supracrustal bands}

Bands of amphibolite, mica schist, siliceous gneiss and marbles occur in the orthogneisses at various localities. On the easternmost nunatak a few 3-5 $\mathrm{m}$ thick bands of dark, garnet mica schist have been traced for some hundred metres, and on the northernmost nunatak a c. 5-10 $\mathrm{m}$ wide marble/amphibolite band has been followed for several hundred metres. These presumed supracrustal rocks are most frequent in Wulff Land. Here prominent dark amphibolite bands are associated in places with bands of grey siliceous gneisses, muscovite schists and siliceous schists (quartzites). The amphibolite bands may reach $30-50 \mathrm{~m}$ in width, but are usually less than $10-20 \mathrm{~m}$ in thickness; they are well foliated hornblende-rich rocks, with plagioclase, quartz and garnet, and with scapolite in a single sample.

The mica schists and the marbles with the associated amphibolite bands are clearly of supracrustal origin, but the origin of the larger amphibolites and the siliceous gneisses in Wulff Land is less certain. All bands are conformable with the adjacent orthogneisses, and no indication of the age relationship between the orthogneisses and the supracrustal rocks has been seen.

\section{Late kinematic quartz-diorite}

An irregularly shaped, late kinematic, homogeneous leucocratic plutonic body about $20 \mathrm{~m}$ by $5 \mathrm{~m}$ in size has been found adjacent to $\mathrm{C}$. $\mathrm{H}$. Ostenfeld Gletscher on the eastern nunatak. It has both sharp and locally transitional boundaries with the surrounding foliated orthogneisses, and includes ghostly remnants of the gneisses; it clearly post-dates the foliation in the gneisses. The body is cut by thin biotite pegmatites and is transected by a $25 \mathrm{~m}$ wide dolerite dyke.

The rock lacks foliation and has an igneous texture with the biotite occurring in clusters. It is medium-grained, contains a high proportion of plagioclase and smaller amounts of quartz and biotite. The plagioclase and the biotite are strongly altered.

A sample for $\mathrm{Zr}$ isotopic age determination work has been collected from the quartz-diorite.

\section{Structures and metamorphism}

The structures in the basement have not been investigated in any detail. In a broad sense the regional dip is to the north, and most measured fold axes have north-easterly to northwesterly trends with gentle plunges. Mesoscopic folds have been observed at all localities and there is evidence of two phases of folding. Migmatisation apparently followed the first phase of deformation, but preceded or was contemporaneous with the second phase.

All the rock types, except the late-kinematic quartz-diorite, have clearly metamorphic textures and were recrystallised under amphibolite facies conditions. The secondary metamorphic alterations are pronounced in and adjacent to crush zones and some joints, but they all reflect a much lower temperature regime and correspond to a later cratogenic epoch. The secondary alterations are frequently associated with a rusty red colouration around $\mathrm{E}-\mathrm{W}$ to 
NW-SE trending mylonites and crush zones. These altered zones can be up to several tens of metres wide, and in some areas on the nunataks the density of the crush zones is so high that it is difficult to find undisturbed fresh outcrops.

\section{Chronology}

A preliminary chronology is suggested. The oldest units are the supracrustal bands with their now orthogneiss host. The emplacement of the basic sills, now amphibolite sheets, took place into a granitic to granodioritic plutonic mass which became the orthogneisses. The basic sheets were dolerites and their few remnant intrusive and plutonic features indicate that they were emplaced in a partly cooled and brittle host rock. After the emplacement of the basic sheets all rock units were subjected to orogenic events with at least two phases of deformation. Regional metamorphism reaching amphibolite facies grade and migmatisation affected the whole area and all rocks were completely recrystallised and foliated. The late kinematic quartz-diorite body, with its preserved plutonic features, is considered as reflecting a late orogenic event together with some of the late pegmatites.

The faults, crush zones and joints with the accompanying retrogression are post orogenic features, and may span over a long period of time from the first uplift into the succeeding cratogenic epoch.

\section{Post orogenic basic dykes}

Parts of three $25 \mathrm{~m}$ wide, E-W trending, near vertical, doleritic dykes have been observed on the central and eastern of the large nunataks. They have a 2-3 m wide chilled contact zone and are otherwise medium-grained with sub-ophitic texture and scattered plagioclase phenocrysts. Their intrusive features, with knife-sharp boundaries, apophyses, local xenoliths and chilled margins, indicate they were emplaced in a brittle, cooled host rock. The dolerites are composed of saussuritized plagioclase, clinopyroxene with uralitic cores, granophyric matrix and about $5 \%$ opaque minerals. The dolerites are petrographically very similar to the quartz-tholeiitic Midsommersø Dolerites (middle Proterozoic) which are exposed $100 \mathrm{~km}$ north-east of the basement area (Kalsbeek \& Jepsen, 1983).

A few thin N-S trending basic dykes and an E-W trending lamprophyre dyke have also been observed.

\section{References}

Dawes, P. R. 1976: Precambrian to Tertiary of northern Greenland. In Escher, A. \& Watt, W. S. (edit.) Geology of Greenland, 248-303. Copenhagen: Geol. Surv. Greenland.

Dawes, P. R. \& Soper, N. J. 1973: Pre-Quaternary history of North Greenland. In Pitcher, M. G. (edit.) Arctic geology. Mem. Am. Ass. Petrol. Geol. 19, 117-134.

Frisch, T. \& Dawes, P. R. 1982: The Precambrian Shield of northernmost Baffin Bay: correlation across Nares Strait. In Dawes, P. R. \& Kerr, J. W. (edit.) Nares Strait and the drift of Greenland: a conflict in plate tectonics. Meddr Grønland, Geosci. 8, 79-88.

Jepsen, H. F. 1971: The Precambrian, Eocambrian and early Proterozoic stratigraphy of the Jørgen Brønlund Fjord area, Peary Land, North Greenland. Bull. Grønlands geol. Unders. 96 (also Meddr Gronland 192,2), 42 pp. 
Jepsen, H. F. \& Kalsbeek, F. 1981: Non-existence of the Carolinidian orogeny in the Prinsesse CarolineMathilde Alper of Kronprins Christian Land, eastern North Greenland. Rapp. Grønlands geol. Unders. 106, 7-14.

Kalsbeek, F. \& Jepsen, H. F. 1983: The Midsommers $\emptyset$ Dolerites and associated intrusions in the Proterozoic Platform of eastern North Greenland - a study of the interaction between intrusive basic magma and sialic crust. J. Petrol. 24, 605-634.

O'Connor, B. 1979: The Portfjeld Formation (?Early Cambrian) of eastern North Greenland. Rapp. Grønlands geol. Unders. 88, 23-28. 